\title{
Synthesis, characterization and crystal structure of new nickel molybdenum complex with the pyridine dicarboxylic acid ligand: Novel precursors for nickel molybdate nanoparticles
}

\author{
HAMID EMADI, BAHAREH TAMADDONI JAHROMI and ALI NEMATI KHARAT* \\ School of Chemistry, University College of Science, University of Tehran, Tehran, Iran \\ Email: alnema@khayam.ut.ac.ir
}

MS received 15 October 2016; revised 6 January 2017; accepted 27 January 2017

\begin{abstract}
A novel nickel molybdenum complex with the 2,6-pyridine dicarboxylic acid ligand was successfully synthesized and characterized by thermogravimetric analysis and single crystal X-ray crystallography. The single-crystal X-ray data revealed that the structure is a hydrated 1-D polymer with two different Ni sites. The synthesized complex was then used as a new precursor for the preparation of the related nickel molybdate nanoparticles. The crystallinity and morphology of the nickel molybdate nanoparticles were characterized by powder X-ray diffraction (XRD), energy-dispersive X-ray spectroscopy (EDS), scanning electron microscopy (SEM), transmittance electron microscopy (TEM), and Photoluminescence (PL) spectroscopy.
\end{abstract}

Keywords. X-ray crystallography; $\mathrm{NiMoO}_{4}$; nanoparticles; electron microscopy.

\section{Introduction}

Synthesis of different metal complexes have been the subject of intensive investigation because of their potential applications in material science as catalytic, conductive, luminescent, magnetic, porous, chiral or nonlinear optical materials. The most useful strategy to construct such materials is to employ appropriate bridging ligands, carboxylate, for example, which is capable of binding metal centers through direct bond formation. Pyridine 2,6-dicarboxylate $\left(\mathrm{pdc}^{2-}\right)$, a ligand in coordination polymers and coordination complexes, is a suitable building block for supramolecular assemblies. ${ }^{1-5}$

Pyridine 2,6-dicarboxylic acid can act as partialy or fully deprotonated species capable of diverse coordination modes. 2,6-pyridine dicarboxylic acid is found to be a suitable ligand as it is a versatile $\mathrm{N}$, $\mathrm{O}$ chelator in coordination chemistry due to its diverse coordination modes. ${ }^{6-8}$ In the present study, mixed complexes of nickel and molybdenum with pyridine 2,6-dicarboxylic acid was synthesized and the product was characterized by x-ray crystallography.

Metal coordination supramolecular compounds as precursors have been widely studied because they play an important role as interface between synthetic chemistry and materials science. ${ }^{9}$ In this study, it is intended to apply such a complex as precursor for synthesis of nickel molybdate. Metal molybdate as an important

*For correspondence inorganic material has attracted increasing attention due to its application as industrial catalysts for partial oxidation of hydrocarbons and as precursors in the synthesis of hydrodesulfurization catalyst, ${ }^{10}$ sensors,${ }^{11}$ scintillator materials, ${ }^{12}$ and for their electrochemical, ${ }^{13}$ and photoluminescence ${ }^{14}$ properties.

The molybdate material, $\mathrm{NiMoO}_{4}$ was applied for alkane dehydrogenation. ${ }^{15}$ Three different phases of nickel molybdate can be found at room temperature including $\alpha-\mathrm{NiMoO}_{4}, \beta-\mathrm{NiMoO}_{4}$, and the hydrate $\mathrm{NiMoO}_{4} \cdot \mathrm{nH}_{2} \mathrm{O}$. ${ }^{16}$ The $\beta$-phase of $\mathrm{NiMoO}_{4}$ showed selectivity for the dehydrogenation of propane to propene twice that of the $\alpha$-phase. ${ }^{15}$ However, among these three polymorphs, $\beta-\mathrm{NiMoO}_{4}$ is stable only at high temperature and will transit to $\alpha$-phase when cooling down to room temperature, which limits its application. ${ }^{15}$ It is therefore significant to synthesize stable $\beta-\mathrm{NiMoO}_{4}$ at room temperature.

Various synthetic routes for nickel molybdate have been followed, including hydrothermal route, ${ }^{17}$ citrate complex route, ${ }^{18}$ solid state synthesis at high temperature, ${ }^{19,20}$ sol-gel method, ${ }^{21}$ coprecipitation from aqueous solutions of soluble salt, ${ }^{22}$ mechanochemical and high pressure methods. ${ }^{18,23}$ Among the various methods for the synthesis of nanoparticles, thermal decomposition is a novel method to prepare stable monodispersed particles which is a rapidly developing research area. $^{22}$ In comparison with other methods, it is much faster, cleaner and economical. However, an improvement in the thermal decomposition process should be 
made for preparing nanoparticles with controllable size and shape.

\section{Experimental}

\subsection{Materials and physical measurements}

All the chemical reagents used in this work were of analytical grade and used as received. Single-crystal $\mathrm{X}$-ray diffraction data were collected on a STOE IPDSII diffractometer with graphite monochromated MoK $\alpha$ radiation at room temperature using the Stoe X-AREA software. $^{24}$ The structure was solved using STR-92 and refined using the full-matrix least-squares methods on F2, within SHELXTL V6.1. ${ }^{25,26}$ Thermogravimetric thermal analysis (TGA) was carried out using a thermal gravimetric analysis instrument (METTLER-SW 9.10). X-ray diffraction (XRD) patterns were recorded by a Philips-X'pertpro, X-ray diffractometer using Nifiltered $\mathrm{Cu} \mathrm{K} \alpha$ radiation. Scanning electron microscopy (SEM) images were taken on ZEISS equipped for energy dispersive X-ray spectroscopy. Elemental analysis was performed with a Heraeus $\mathrm{CHN}-\mathrm{O}$ Rapid analyzer. Transmission electron microscopy (TEM) image was obtained on a Philips EM280 transmission electron microscope with an accelerating voltage of $150 \mathrm{kV}$. Photoluminescence (PL) spectrum was obtained using
Table 2. Selected Bond lengths $[\AA]$ in $\mathrm{C}_{14} \mathrm{H}_{18} \mathrm{Mo}_{0.22} \mathrm{~N}_{2}$ $\mathrm{Ni}_{1.78} \mathrm{O}_{14}$.

\begin{tabular}{ll} 
Mo(1)-N(2)\#1 & $1.963(4)$ \\
Mo(1)-N(1) & $1.964(4)$ \\
Mo(1)-O(8)\#1 & $2.110(4)$ \\
Mo(1)-O(2) & $2.114(4)$ \\
Mo(1)-O(3) & $2.129(4)$ \\
Mo(1)-O(6)\#1 & $2.163(4)$ \\
Ni(1)-O(12) & $2.159(4)$ \\
Ni(1)-O(11) & $2.166(4)$ \\
Ni(1)-O(1) & $2.178(4)$ \\
Ni(1)-O(9) & $2.196(4)$ \\
Ni(1)-O(5) & $2.205(4)$ \\
Ni(1)-O(10) & $2.214(4)$ \\
O(1)-C(1) & $1.250(6)$ \\
O(2)-C(1) & $1.265(6)$ \\
O(3)-C(7) & $1.268(6)$ \\
O(6)-C(8) & $1.258(6)$ \\
O(6)-Ni(2)\#2 & $2.163(4)$ \\
O(6)-Mo(1)\#2 & $2.163(4)$ \\
O(7)-C(14) & $1.240(6)$ \\
O(8)-C(14) & $1.285(6)$ \\
O(8)-Ni(2)\#2 & $2.110(4)$ \\
O(8)-Mo(1)\#2 & $2.110(4)$ \\
O(9)-H(91) & 0.8400 \\
O(9)-H(92) & 0.8401 \\
O(10)-H(101) & 0.8400 \\
O(10)-H(102) & 0.8399 \\
O(12)-H(122) & 0.8400 \\
N(1)-C(2) & $1.340(7)$ \\
N(1)-C(6) & $1.344(7)$ \\
N(2)-C(13) & $1.333(7)$ \\
N(2)-C(9) & $1.333(7)$ \\
N(2)-Ni(2)\#2 & $1.963(4)$ \\
N(2)-Mo(1)\#2 & $1.963(4)$ \\
\hline &
\end{tabular}

Table 1. Crystal data and structure refinement for $\mathrm{C}_{14} \mathrm{H}_{18} \mathrm{Mo}_{0.22} \mathrm{~N}_{2} \mathrm{Ni}_{1.78} \mathrm{O}_{14}$.

\begin{tabular}{|c|c|c|}
\hline Identification code & K11249 & \\
\hline Empirical formula & $\mathrm{C}_{14} \mathrm{H}_{18} \mathrm{Mo}_{0.22} \mathrm{~N}_{2} \mathrm{Ni}_{1.78} \mathrm{O}_{14}$ & \\
\hline Formula weight & 563.91 & \\
\hline Temperature & $150(1) \mathrm{K}$ & \\
\hline Wavelength & $0.71073 \AA$ & \\
\hline Crystal system & Triclinic & \\
\hline Space group & $\mathrm{P}-1$ & \\
\hline \multirow[t]{3}{*}{ Unit cell dimensions } & $\mathrm{a}=8.4432(3) \AA$ & $\alpha=81.270(2)^{\circ}$ \\
\hline & $\mathrm{b}=8.5677(3) \AA$ & $\beta=73.344(2)^{\circ}$ \\
\hline & $\mathrm{c}=13.8977(4) \AA$ & $\gamma=89.492(2)^{\circ}$ \\
\hline Volume & $951.37(5) \AA^{3}$ & \\
\hline $\mathrm{Z}$ & 2 & \\
\hline Density (calculated) & $1.969 \mathrm{Mg} / \mathrm{m}^{3}$ & \\
\hline Absorption coefficient & $1.989 \mathrm{~mm}^{-1}$ & \\
\hline $\mathrm{F}(000)$ & 574 & \\
\hline Crystal size & $0.14 \times 0.12 \times 0.08 \mathrm{~mm}^{3}$ & \\
\hline Theta range for data collection & 2.55 to $27.51^{\circ}$ & \\
\hline Index ranges & $-10<=\mathrm{h}<=10,-10<=\mathrm{k}<=11,-18<=\mathrm{l}<=17$ & \\
\hline Reflections collected & 16688 & \\
\hline Independent reflections & $4359[\mathrm{R}$ (int) $=0.0696]$ & \\
\hline Completeness to theta $=27.51^{\circ}$ & $99.6 \%$ & \\
\hline Absorption correction & Semi-empirical from equivalents & \\
\hline Max. and min. transmission & 0.798 and 0.727 & \\
\hline Refinement method & Full-matrix least-squares on $\mathrm{F}^{2}$ & \\
\hline Data / restraints / parameters & $4359 / 0 / 290$ & \\
\hline Goodness-of-fit on $\mathrm{F}^{2}$ & 1.054 & \\
\hline Final R indices [I>2sigma(I)] & $\mathrm{R} 1=0.0628, w \mathrm{R} 2=0.1624$ & \\
\hline $\mathrm{R}$ indices (all data) & $\mathrm{R} 1=0.1016, \mathrm{wR} 2=0.1934$ & \\
\hline Largest diff. peak and hole & 1.351 and -1.952 e. $\AA$ & \\
\hline
\end{tabular}


a Perkin-Elmer LS-55 luminescence spectrometer with an excitation and emission slit widths of $5 \mathrm{~nm}$ each.

\subsection{Synthesis of $\mathrm{C}_{14} \mathrm{H}_{18} \mathrm{Mo}_{0.22} \mathrm{~N}_{2} \mathrm{Ni}_{1.78} \mathrm{O}_{14}$}

To synthesize the complex, $2 \mathrm{mmol}$ of $\mathrm{Na}_{2} \mathrm{MoO}_{4} \cdot 2 \mathrm{H}_{2} \mathrm{O}$, $2 \mathrm{mmol}$ of $\mathrm{Ni}\left(\mathrm{NO}_{3}\right)_{2} \cdot 6 \mathrm{H}_{2} \mathrm{O}$, and $1 \mathrm{mmol}$ of 2,6-pyridine dicarboxylic acid were dissolved in $10 \mathrm{~mL}$ distilled water separately. After 15 min, all of the solutions were mixed and refluxed for $2 \mathrm{~h}$. Crystallization from hot water afforded the analytically pure, pale green complex suitable for X-ray crystallography ( $74 \%$ yield).

\subsection{Preparation of $\mathrm{NiMoO}_{4}$ nanoparticles}

In a typical synthetic route, $1 \mathrm{~g}$ of complex was put in a crucible and then heated in a furnace at $450^{\circ} \mathrm{C}$ for different reaction times. Then, it was cooled to room temperature to obtain $\mathrm{NiMoO}_{4}$ as a green-yellow precipitate.

\section{Results and discussion}

Crystallographic data (CCDC 1511673) and selected bond lengths $(\AA)$ and angles $\left({ }^{\circ}\right)$ are listed in Tables 1 and 2, respectively. $\mathrm{C}_{14} \mathrm{H}_{18} \mathrm{Mo}_{0.22} \mathrm{~N}_{2} \mathrm{Ni}_{1.78} \mathrm{O}_{14}$ crystallizes as green blocks in the triclinic space group P-1 with two molecules in the unit cell. Nickel ion is six-coordinated, comprising of four oxygen atoms and two nitrogen atoms from the two pyridine dicarboxylic groups which appear to be a mixed metal site that is occupied by the heavier Mo approximately $22 \%$ of the time. The Ni1 site is $100 \%$ also six coordinated

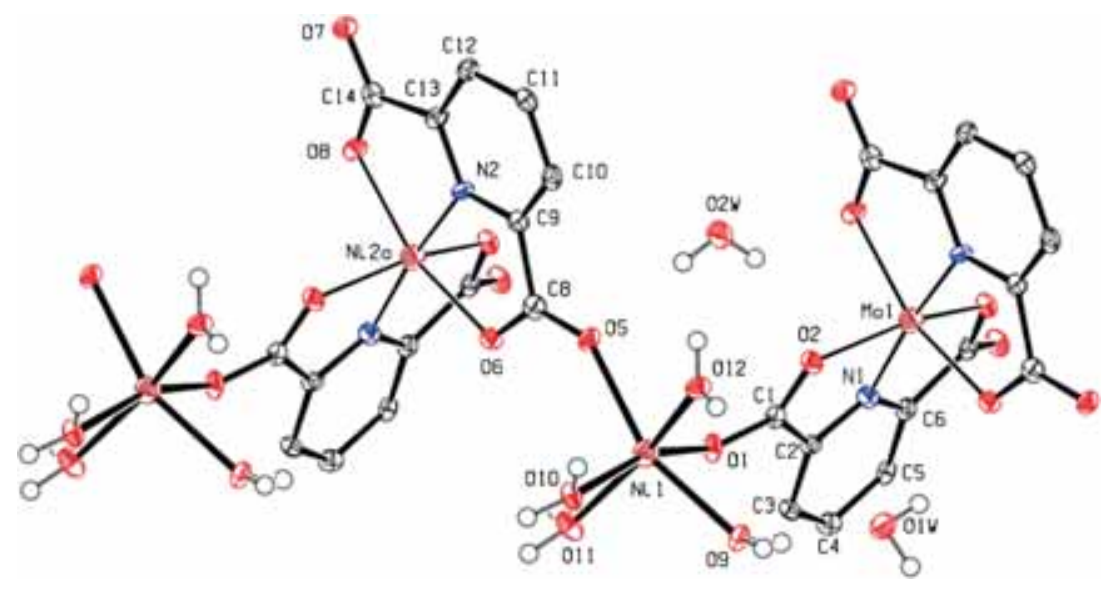

Figure 1. ORTEP structure of $\mathrm{C}_{14} \mathrm{H}_{18} \mathrm{Mo}_{0.22} \mathrm{~N}_{2} \mathrm{Ni}_{1.78} \mathrm{O}_{14}$ with atom numbering scheme. The thermal ellipsoids are drawn at the $50 \%$ probability level at $150 \mathrm{~K}$.

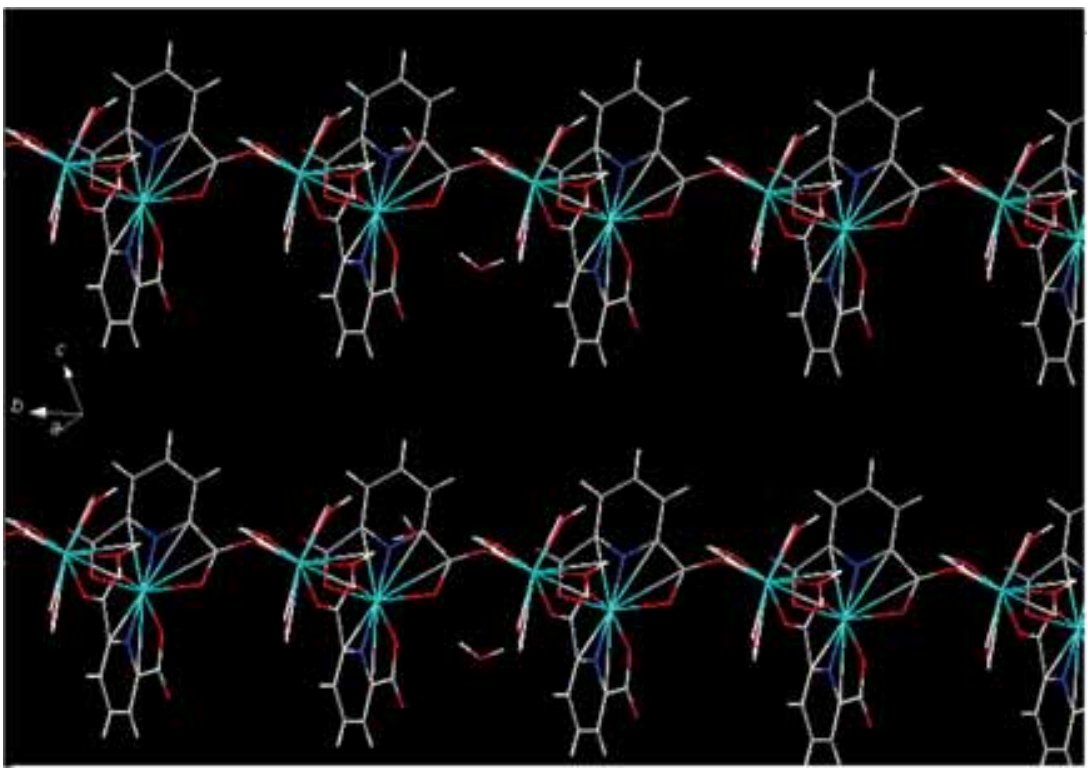

Figure 2. View of 1-D chains in the structure. 
with two oxygen atoms from two different pyridine dicarboxylic acid ligands and four oxygen atoms from four molecules of water (Figure 1). As can be seen in Figure 2, this complex is a hydrated 1-D polymer.

The nickel-oxygen bond distance is 2.166(3) $\AA$ for oxygen of coordinated water, and 2.164(3) $\AA$ for bidentate carboxylic acid, which are comparable with reported bond lengths for a six-coordinated nickel complex. ${ }^{27-29}$ Some weak hydrogen bonds exist in the structure, stabilizing the packing of the complex which belongs to $\mathrm{C}-\mathrm{H} \cdots \pi$ interaction of the pyridine groups (Figure 3). Crystallographic data, selected bond lengths $(\AA)$ and angles of $\mathrm{C}_{14} \mathrm{H}_{18} \mathrm{Mo}_{0.22} \mathrm{~N}_{2} \mathrm{Ni}_{1.78} \mathrm{O}_{14}$ are given in Tables 1, 2 and 3 .

In order to investigate the purity of the complex, CHN elemental analysis was employed. Anal. Calc. for $\mathrm{C}_{14} \mathrm{H}_{18} \mathrm{Mo}_{0.22} \mathrm{~N}_{2} \mathrm{Ni}_{1.78} \mathrm{O}_{14}$ : C, 29.82\%; $\mathrm{H}, 3.22 \%$; , 4.97\%; Found: C, 29.85\%; H, 3.23\%; N, 4.99\%.

The complex was loaded in the platinum crucible and heated at a rate of $10^{\circ} \mathrm{C} / \mathrm{min}$ in air. TGA curve of the complex is shown in Figure 4. As can be seen, at the first step located at $90-120^{\circ} \mathrm{C}$ both adsorbed and coordinated water molecules are lost and at the second step $\left(270-420^{\circ} \mathrm{C}\right)$ the decomposition of the organic template took place. Therefore, the choice of appropriate calcination temperature was chosen $450^{\circ} \mathrm{C}$ based on TG analysis.

XRD pattern of the product was obtained. All the diffraction peaks in XRD (Figure 5) can be indexed to the monoclinic crystal structure of $\beta-\mathrm{NiMoO}_{4}$ (group space group $\mathrm{C} 12 / \mathrm{m} 1$ ) which is very close to the values in the literature (JCPDS No. 12-0348 with lattice parameters $\mathrm{a}=10.094 \AA, \mathrm{b}=9.203 \AA, \mathrm{c}=6.996 \AA$ ).
Table 3. Selected angles $\left[^{\circ}\right]$ for $\mathrm{C}_{14} \mathrm{H}_{18} \mathrm{Mo}_{0.22} \mathrm{~N}_{2} \mathrm{Ni}_{1.78} \mathrm{O}_{14}$.

$\mathrm{N}(2) \# 1-\mathrm{Mo}(1)-\mathrm{O}(2)$

$\mathrm{N}(1)-\mathrm{Mo}(1)-\mathrm{O}(2)$

$\mathrm{N}(1)-\mathrm{Mo}(1)-\mathrm{O}(3)$

$\mathrm{O}(11)-\mathrm{Ni}(1)-\mathrm{O}(9)$

$\mathrm{O}(1)-\mathrm{Ni}(1)-\mathrm{O}(9)$

$\mathrm{O}(12)-\mathrm{Ni}(1)-\mathrm{O}(5)$

$\mathrm{O}(11)-\mathrm{Ni}(1)-\mathrm{O}(5)$

$\mathrm{O}(1)-\mathrm{Ni}(1)-\mathrm{O}(5)$

$\mathrm{O}(9)-\mathrm{Ni}(1)-\mathrm{O}(10)$

$\mathrm{O}(5)-\mathrm{Ni}(1)-\mathrm{O}(10)$

$\mathrm{Ni}(1)-\mathrm{O}(12)-\mathrm{H}(122)$

$\mathrm{H}(121)-\mathrm{O}(12)-\mathrm{H}(122)$

$\mathrm{C}(2)-\mathrm{N}(1)-\mathrm{C}(6)$

$\mathrm{C}(2)-\mathrm{N}(1)-\mathrm{Mo}(1)$

C(6)-N(1)-Mo(1)

C(13)-N(2)-C(9)

$\mathrm{C}(13)-\mathrm{N}(2)-\mathrm{Ni}(2) \# 2$

$\mathrm{C}(9)-\mathrm{N}(2)-\mathrm{Ni}(2) \# 2$

C(13)-N(2)-Mo(1)\#2

$\mathrm{C}(9)-\mathrm{N}(2)-\mathrm{Mo}(1) \# 2$

$\mathrm{O}(1)-\mathrm{C}(1)-\mathrm{C}(2)$

$\mathrm{O}(2)-\mathrm{C}(1)-\mathrm{C}(2)$

$\mathrm{N}(1)-\mathrm{C}(2)-\mathrm{C}(3)$

$\mathrm{C}(3)-\mathrm{C}(4)-\mathrm{C}(5)$

C(3)-C(4)-H(4A)

$\mathrm{C}(5)-\mathrm{C}(4)-\mathrm{H}(4 \mathrm{~A})$

$\mathrm{C}(6)-\mathrm{C}(5)-\mathrm{C}(4)$

$\mathrm{N}(1)-\mathrm{C}(6)-\mathrm{C}(7)$

$\mathrm{C}(10)-\mathrm{C}(9)-\mathrm{C}(8)$

$\mathrm{C}(9)-\mathrm{C}(10)-\mathrm{C}(11)$

C(12)-C(13)-C(14)

$101.75(16)$

$78.17(16)$

$78.30(16)$

$100.05(15)$

$80.32(14)$

$81.70(14)$

98.24(15)

92.66(14)

92.13(14)

99.71(14)

126.1

97.3

$121.8(5)$

$118.2(3)$

$118.8(4)$

$122.2(5)$

$118.6(4)$

119.1(3)

$118.6(4)$

119.1(3)

$118.0(5)$

$115.6(4)$

$120.4(5)$

$120.2(5)$

119.9

119.9

$118.8(5)$

$111.7(4)$

$126.0(5)$

$118.0(5)$

125.9(5)

$\overline{\text { Symmetry transformations used to generate equivalent }}$ atoms: \#1 x,y+1,z \#2 x,y-1,z.

Acceptable matches are observed for the compound indicating the presence of only one crystalline phase in the sample. Broader peaks in XRD pattern confirms the

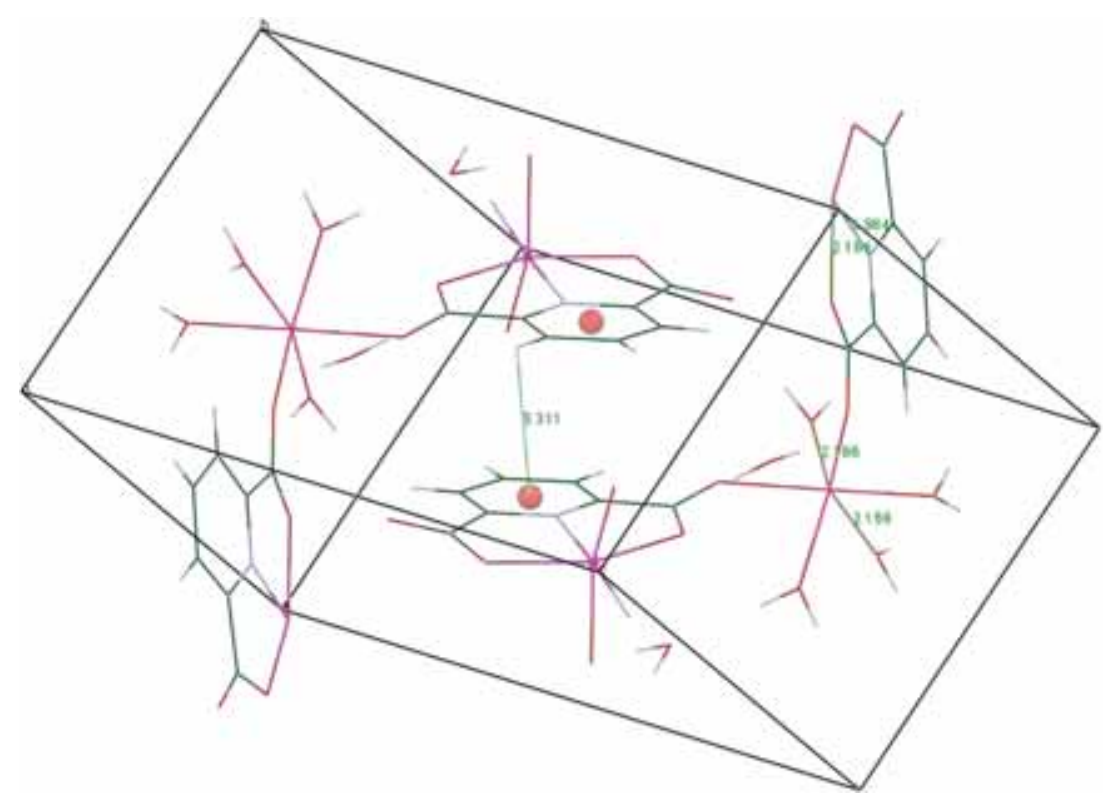

Figure 3. View of bond distances and $\mathrm{C}-\mathrm{H} \cdots \pi$ interactions in the packing. 


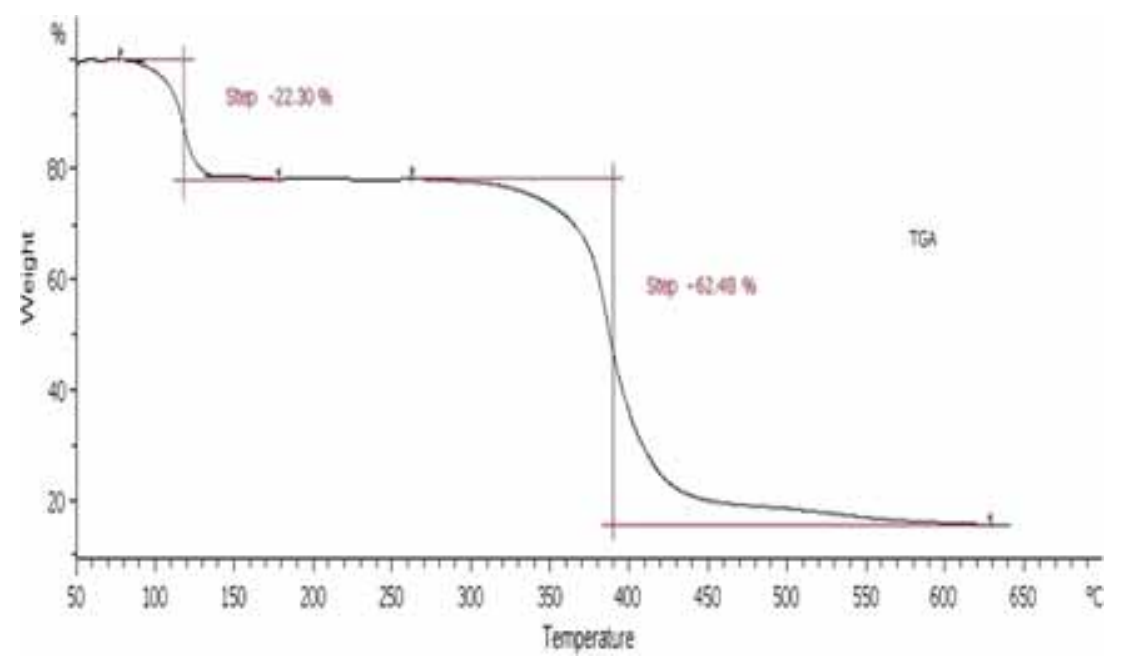

Figure 4. TGA curve of the synthesized complex.

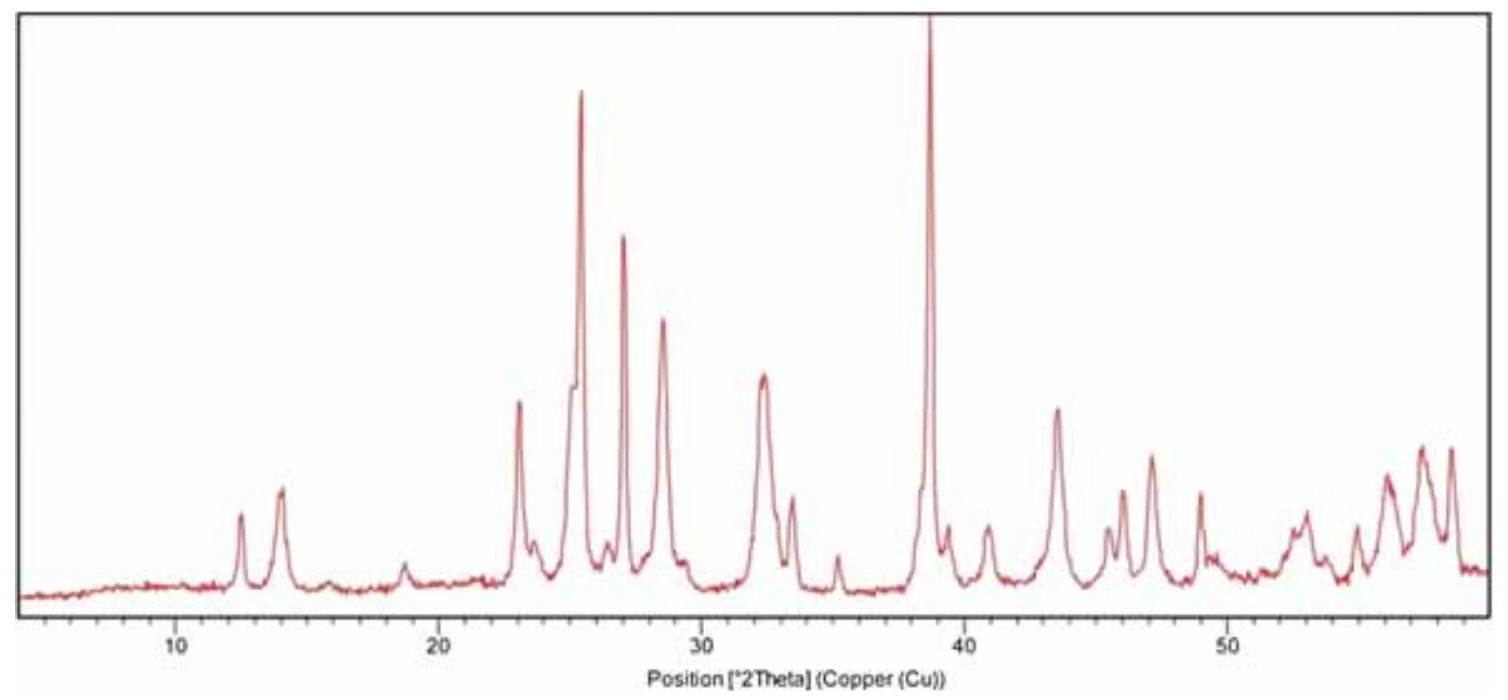

Figure 5. XRD pattern of $\mathrm{NiMoO}_{4}$ nanoparticles.

small size of the particle. The average crystallite diameter of the product was estimated from Debye-Scherrer equation: $D c=\frac{\mathrm{k} \lambda}{\beta \cos \theta}$; Where $\beta$ is the width of the observed diffraction line at its half-intensity maximum, $\mathrm{k}$ is the so-called shape factor, and $\lambda$ is the wavelength of X-ray source used in XRD. The average crystallite diameter of the product was determined as $\sim 51 \mathrm{~nm}$.

EDS analysis was applied to characterize product composition. Figure 6 clearly demonstrates that the product is mainly composed of $\mathrm{Ni}, \mathrm{Mo}$ and $\mathrm{O}$ and their ratio is close to $1: 1: 4$.

SEM images were used to investigate morphology of the samples. As can be seen in Figure 7a, the samples synthesized at reaction time of $4 \mathrm{~h}$ were not uniform and the particles were not separated well. When reaction time was increased to $8 \mathrm{~h}$, nanoparticles of $\mathrm{NiMoO}_{4}$ with uniform size distribution were obtained
(Figure $7 \mathrm{~b}$ ). Further increasing of the reaction time to $16 \mathrm{~h}$ led to the formation of agglomerated particles in the shape of the sheets (Figure 7c). TEM image of the sample obtained at $8 \mathrm{~h}$ (Figure $7 \mathrm{~d}$ ) confirms that the particle size is around $35-45 \mathrm{~nm}$, which is close to the crystal diameter calculated by Scherrer equation.

To study the optical properties of $\mathrm{NiMoO}_{4}$ nanoparticles, as-prepared samples were ultrasonically dispersed in absolute ethanol. The optical transitions of molybdate is usually attributed to the radiative recombination of the electron-hole pairs localized at the $\left[\mathrm{MoO}_{4}^{2}\right]$ group. ${ }^{30,31}$ The top of the valence band of the lowest unoccupied states are composed of the $4 \mathrm{~d}$ Mo states split into two sets of bands with e (primarily Mo 4d) and t (primarily O $2 \mathrm{p} \pi$ ) symmetry. ${ }^{16}$ The composite emission bands in the PL spectrum can be assigned to the electronic transitions from the valence 


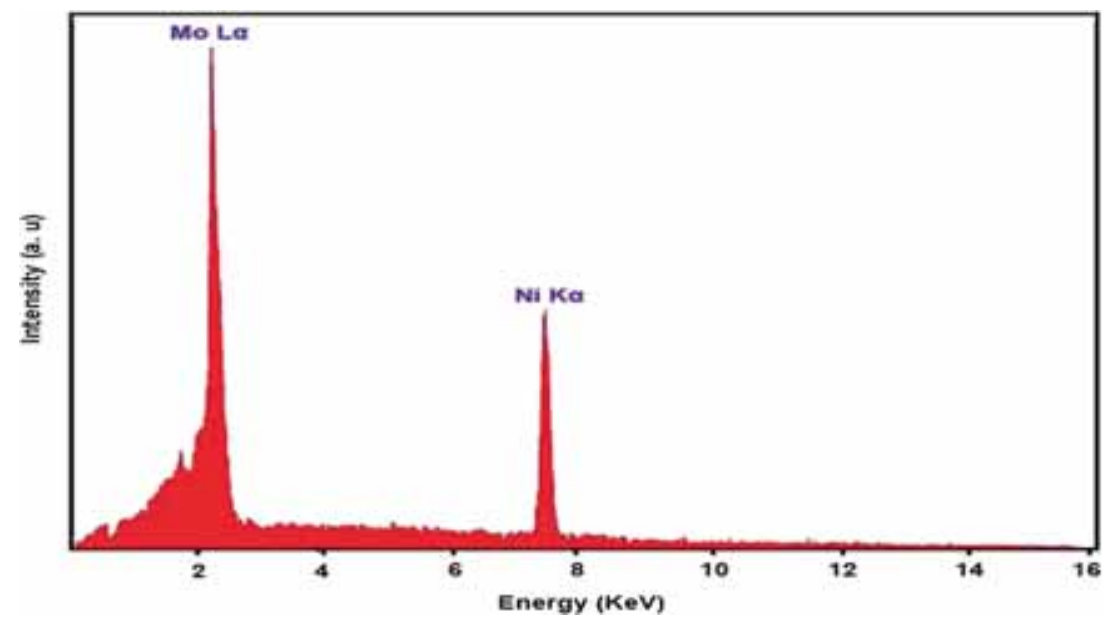

Figure 6. EDS spectrum of the $\mathrm{NiMoO}_{4}$ nanoparticles.

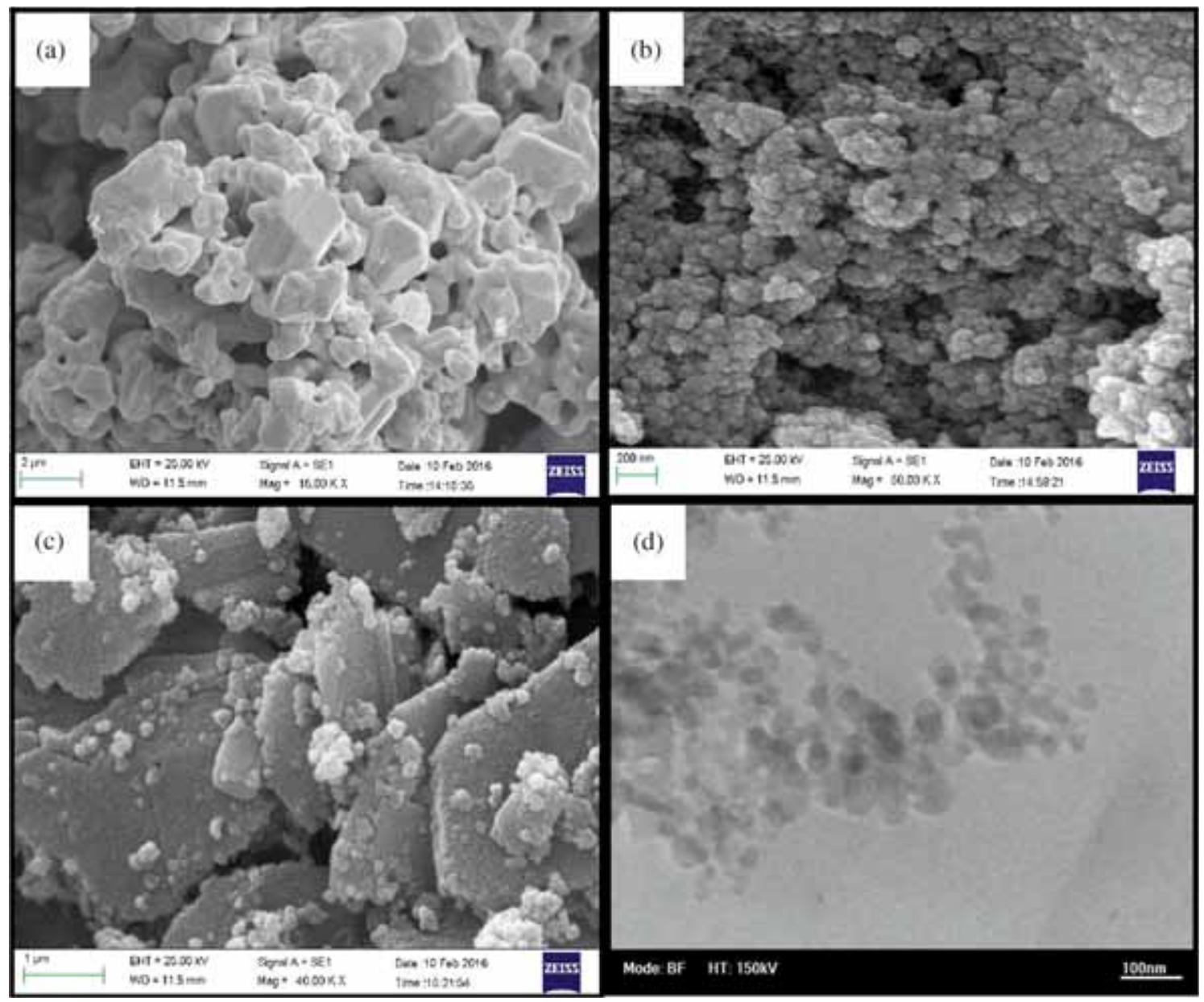

Figure 7. SEM images of the samples obtained at $450^{\circ} \mathrm{C}$ for reaction time of, (a) $4 \mathrm{~h}$; (b) $8 \mathrm{~h}$; and (c) $16 \mathrm{~h}$. TEM image of the sample synthesized at $450^{\circ} \mathrm{C}$ and $8 \mathrm{~h}$.

O 2p-states to the Mo 4d-states, which have different symmetry. ${ }^{18}$ Photoluminescence (PL) spectrum of the $\mathrm{NiMoO}_{4}$ nanoparticles is presented in Figure 8. A sharp peak centered at $621 \mathrm{~nm}$ was observed and the band gap of sample was calculated to be $1.99 \mathrm{eV}$, which showed $0.2 \mathrm{eV}$ blue shift (band gap of bulk samples of $\mathrm{NiMoO}_{4}=1.79 \mathrm{eV}$ ), suggesting that the nanoparticles behave within the quantum confined regime. ${ }^{32}$ 


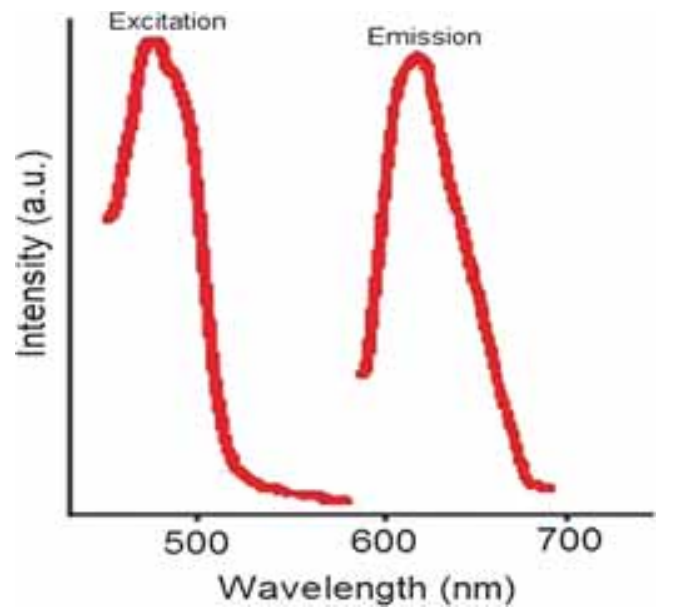

Figure 8. PL spectra of the synthesized nanoparticles $\left(\lambda_{\text {exc }}=455 \mathrm{~nm} ; \lambda_{\mathrm{em}}=621 \mathrm{~nm}\right.$; and concentration is $2 \mathrm{mg} / \mathrm{mL}$ in ethanol).

\section{Conclusions}

A new complex of nickel and molybdenum with 2,6pyridine dicarboxylic acid ligand was synthesized. Single-crystal X-ray data confirmed a hydrated 1-D polymer with two different Ni sites for this complex. The complex was used as precursor for synthesis of $\mathrm{NiMoO}_{4}$ nanoparticles. The samples obtained at $450^{\circ} \mathrm{C}$ and $8 \mathrm{~h}$ were nanoparticles with size of $35-45 \mathrm{~nm}$ and confirmed by TEM. Further increase in thermal decomposition time led to nanosheet-like structures.

\section{Acknowledgements}

The authors gratefully acknowledge the financial support from Iran National Science Foundation (INSF).

\section{References}

1. Zhao B, Cheng P, Dai Y, Cheng C, Liao D Z, Yan S P, Jiang Z H and Wang G L 2003 A Nanotubular 3D Coordination Polymer Based on a $3 \mathrm{~d}-4 \mathrm{f}$ Heterometallic Assembly Angew. Chem. Int. Ed. 42934

2. Cui S X, Zhao Y L, Li B, Zhang J P, Liu Q and Zhang Y 2008 Structural and magnetic properties of one-dimensional polymeric Co ${ }^{\mathrm{II}}$ complexes Polyhedron 27671

3. Sutradhard D, Chowdhury H, Koner S, Roy S and Ghosh B K 2016 Two new hexacoordinated coordination polymers of cadmium(II) containing bridging units only: Syntheses, structures and molecular properties J. Chem. Sci. 1281377

4. Li Y, Zhang W L, Du H J, Wang C H, Lu Y B and Niu Y Y 2015 Three silver (I) supramolecular compounds constructed from pyridinium or methylimidazoliumpolycations: Synthesis, crystal structure and properties J. Chem. Sci. 1271513
5. Baruah J B 2011 Synthesis of first row transition metal carboxylate complexes by ring opening reactions of cyclic anhydrides J. Chem. Sci. 123123

6. Aghajani Z, Sharif M A, Aghabozorg $\mathrm{H}$ and Naderpour A 2006 Bis (2,4,6-triamino-1,3,5-triazin-1-ium) bis(pyridine2,6-dicarboxylato)zincate(II) decahydrate Acta Crystallogr. 62830

7. Chatterjee M, Maji M and Ghosh S 1998 Studies of V(III) complexes with selected $\alpha$-N-heterocyclic carboxylato NO donor ligands: Structure of a new sevencoordinated pentagonal bipyramidal complex containing picolinato ligands Dalton Trans. 213641

8. Gangu K K, Dadhich A S and Mukkamala S B 2015 Hydrothermal synthesis, crystal structure and luminescence property of a three dimensional Sm(III) coordination polymer with 2,5-pyridinedicarboxylic acid J. Chem. Sci. 1272225

9. Emadi H and Salavati-Niasari M 2013 Hydrothermal synthesis and characterization of lead sulfide nanocubes through simple hydrothermal method in the presence of [bis(salicylate)lead(II)] as a new precursor Superlattices Microstruct. 54118

10. Kianpour G, Salavati-Niasari M and Emadi H 2013 Precipitation synthesis and characterization of cobalt molybdates nanostructures Superlattices Microstruct. 58120

11. Sundaram R and Nagaraja K S 2004 Solid state electrical conductivity and humidity sensing studies on metal molybdate-molybdenum trioxide composites (M $=\mathrm{Ni}^{2+}, \mathrm{Cu}^{2+}$ and $\mathrm{Pb}^{2+}$ ) Sens. Actuators, B 101353

12. Ryu J H, Yoon J W, Lim C S and Shim K B 2006 Microwave-assisted synthesis of $\mathrm{MWO}_{4}$ and $\mathrm{MMoO}_{4}$ $(\mathrm{M}=\mathrm{Ca}, \mathrm{Ni})$ nano-powders using citrate complex precursor Key Eng. Mater. 317-318 223

13. Xiao W, Chen J S, Li C M, Xu R and Lou X W 2010 Synthesis, characterization, and lithium storage capability of $\mathrm{AMoO}_{4}(\mathrm{~A}=\mathrm{Ni}, \mathrm{Co})$ Nanorods Chem. Mater. 22 746

14. Liu J P, Huang X T, Li Y Y and Li Z K J 2007 A general route to thickness-tunable multilayered sheets of sheelite-type metal molybdate and their self-assembled films J. Mater. Chem. 172754

15. Cao Z, Zhang D, Xu C, Zhang R and Yuan B 2015 A novel enzyme-free glucose sensor based on nickel molybdatenanosheets Int. J. Electrochem. Sci. 103152

16. Kianpour G, Salavati-Niasari M and Emadi H 2013 Sonochemical synthesis and characterization of $\mathrm{NiMoO}_{4}$ nanorods Ultrason. Sonochem. 20418

17. Eda K, Kato Y, Ohshiro Y, Sugitani T and Whittingham M S 2010 Synthesis, crystal structure, and structural conversion of $\mathrm{Ni}$ molybdate hydrate $\mathrm{NiMoO}_{4} \cdot n \mathrm{H}_{2} \mathrm{O}$ J. Solid State Chem. 1831334

18. Ryu J H, Koo S M, Yoon J W, Lim C H and Shim K B 2006 Synthesis of nanocrystalline $\mathrm{MMoO}_{4}(\mathrm{M}=$ $\mathrm{Ni}, \mathrm{Zn}$ ) phosphors via a citrate complex route assisted by microwave irradiation and their photoluminescence Mater. Lett. 601702

19. Smith G W 1962 The crystal structures of cobalt molybdate $\mathrm{CoMoO}_{4}$ and nickel molybdate $\mathrm{NiMoO}_{4}$ Acta Crystallogr. 151054

20. Sieber K, Kershaw R, Dwight K and Wold A 1983 Dependence of magnetic properties on structure in the systems $\mathrm{NiMoO}_{4}$ and $\mathrm{CoMoO}_{4}$ Inorg. Chem. 222667 
21. Maione A and Devilers M 2004 Solid solutions of Ni and Co molybdates in silica-dispersed and bulk catalysts prepared by sol-gel and citrate methods J. Solid State Chem. 1772339

22. Kaddouri A, Del Rosso R, Mazzocchia C, Gronchia $\mathrm{P}$ and Ge Centola $\mathrm{P} 1999$ On the reactivity of $\mathrm{K}_{2} \mathrm{O}-$, $\mathrm{CaO}$ - and $\mathrm{P}_{2} \mathrm{O}_{5}$-doped nickel molybdate catalysts in a periodic-flow reactor Catal. Lett. 6365

23. Klissurski D, Mancheva M, Iordanova R, Tyuliev G and Kunev B 2006 Mechanochemical synthesis of nanocrystalline nickel molybdates J. Alloys Compd. $\mathbf{4 2 2} 53$

24. Stoe \& Cie 2000X-STEP32, Version 1.07b: Crystallographic package Stoe \& Cie GmbH Darmstadt, Germany

25. Altomare A, Cascarano G and Giacovazzo C 1994 A program for automatic solution of crystal structures by direct methods optimized for powder data J. Appl. Cryst. 27435

26. Sheldrick G M 2008 A short history of SHELX Acta Crystallogr. A 64112
27. Drummond J and Wood J S 1970 Crystal and molecular structure of tetraphenylarsoniumtetranitratomanganate (II) and X-ray study of other $\mathrm{M}\left(\mathrm{NO}_{3}\right) 42-$ ions $(\mathrm{M}=$ $\mathrm{Ni}, \mathrm{Cu}$, or $\mathrm{Zn}$ ) J. Chem. Soc. A 226

28. Kongshaug K O and Fjellvag H 2003 Novel coordination polymers based on nickel(II) and 2,6naphthalenedicarboxylate Solid State Sci. 5303

29. Hay R W, Albedyhl S and Lightfoot P 1998 The crystal structure of [ $\mathrm{Ni}(\mathrm{dmf}) 6][\mathrm{NiCl} 4]$ and comments on the hydrolysis of coordinated amides and peptides in metal complexes Trans. Met. Chem. 23257

30. Blasse G 1980 In Luminescence and energy transfer (Berlin: Springer)

31. Graser R, Pitt E, Scharmann A and Zimmerer G 1975 Optical properties of $\mathrm{CaWO}_{4}$ and $\mathrm{CaMoO}_{4}$ crystals in the 4 to $25 \mathrm{eV}$ region Phys. Status Solidi B 69359

32. Matar S F, Largeteau A and Demazeau G $2010 \mathrm{AMoO}_{4}$ $(\mathrm{A}=\mathrm{Mg}, \mathrm{Ni})$ molybdates: Phase stabilities, electronic structures and chemical bonding properties from first principles Solid State Sci. 121779 